
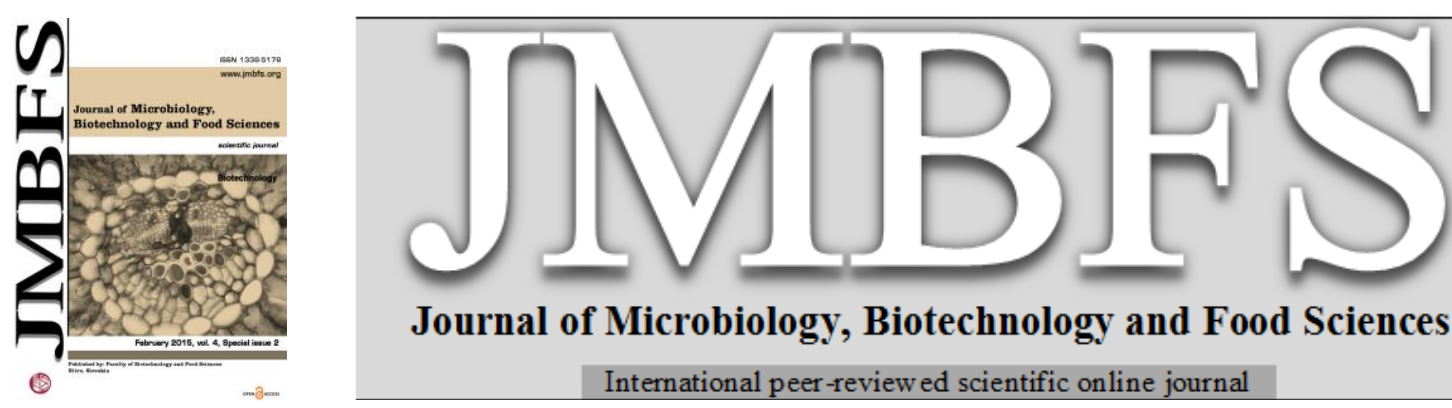

Journal of Microbiology, Biotechnology and Food Sciences

International peer-review ed scientific online journal

\title{
DECOLORISATION OF AQUEOUS SOLUTIONS OF SYNTHETIC DYES BY Lentinus polychrous Lév. CULTIVATED ON CASSAVA RHIZOME
}

\section{Jirachaya Boonyarit ${ }^{1}$, Amornrat Promboon ${ }^{2}$, Nuttakan Nitayapat ${ }^{* 1}$}

Address(es): Nuttakan Nitayapat

${ }^{1}$ Kasetsart University, Faculty of Agro-Industry, Department of Biotechnology, 50 Ngam Wong Wan Road, Chatuchak, Bangkok 10900, Thailand. Tel: ++66 2 5625083

${ }^{2}$ Kasetsart University, Faculty of Science, Department of Biochemistry, 50 Ngam Wong Wan Road, Chatuchak, Bangkok 10900, Thailand.

*Corresponding author: nuttakan.n@ku.ac.th

doi: 10.15414/jmbfs.2015.4.special2.132-137

\section{ARTICLE INFO}

Received 4. 12. 2014

Revised 20. 1. 2015

Accepted 7. 1. 2015

Published 2. 3. 2015

Regular article open $\partial_{\text {ACCESS }}$

\begin{abstract}
Cassava rhizomes are left in fields after harvesting. This agricultural waste is rich in lignocellulosic material which is a substrate for white rot fungi. Disposal of synthetic dyes poses a problem to the environment and it needs to be addressed. The ability of Lentinus polychrous Lév., a white rot fungus, grown on the cassava rhizome chips, to decolorise three kinds of synthetic dye was studied. The effects of the initial moisture content of cassava rhizome used for fungal cultivation, the temperature during the decolorisation, and the $\mathrm{pH}$ of synthetic dye solution on the extent of decolorisation were investigated. The decolorisations of Reactive blue 49, Navy blue and Acid blue 62 were affected by the initial moisture content of cassava rhizome. The highest extents of decolorisation of these dyestuffs were observed when the fungus was cultivated at $70 \%$ initial moisture content. Temperatures of 30,37 and $45^{\circ} \mathrm{C}$ did not alter the extent of decolorisation of the dyestuffs. The most extensive decolorisations of Reactive blue 49 and Acid blue 62 (anthraquinone dyes) were at $\mathrm{pH} 3.0$ while that of Navy blue (azo dye) was at pH 7.0. Adsorption was the main mechanism of decolorisation of Navy blue. However, both enzymic degradation and adsorption were involved in the decolorisations of Reactive blue 49 and Acid blue 62 .
\end{abstract}

Keywords: Agricultural waste, cassava, decolorisation, dye, Lentinus polychrous

\section{INTRODUCTION}

Cassava is a plant with large tuberous roots and it is a major source of dietary carbohydrate in tropical and subtropical regions. The rhizome and the lower part of the stalk $15 \mathrm{~cm}$ above ground are normally left in the fields and burned after the harvest. In this work, these are termed cassava rhizome. Cassava plantations worldwide can be estimated [using the estimates and reports of FAOSTAT (FAO, 2014)] to have occupied 117 million ha in 2013. If 9,000 - 10,000 cassava plants are cultivated per ha, over 1 trillion cassava plants are grown annually. Pattiya $\boldsymbol{e t}$ al. (2010) reported that cassava rhizome contained $27.82 \%$ cellulose, $39.67 \%$ hemicelluloses, and $21.71 \%$ lignin. Given this composition, cassava rhizome has the potential of being used as a substrate for the growth of white rot fungi. The potential use of cassava rhizome for gasification (Sornkade et al., 2014; 2013) and pyrolysis (Homchat et al., 2012; Sirijanusorn et al., 2013; Suttibak et al., 2012) has been suggested.

Synthetic dyes are widely used in textile industries and are discarded in wastewater from the dyeing process. The discharge of these colored wastewaters into rivers and lakes leads to reduced sunlight penetration, which in turn causes a reduction of photosynthetic activity and dissolved oxygen concentration (Sukumar et al., 2007). Biological treatment of wastewater contaminated with synthetic dyes has been studied extensively. One group of microorganisms used for these treatments is the white rot fungi. These fungi are capable of degrading recalcitrant compounds including synthetic dyes by the action of their ligninolytic enzymes, mainly lignin peroxidase, manganese peroxidase and laccase. Some white rot fungi produce all three enzymes, others produce at least one (Wesenberg et al., 2003).

Lentinus polychrous Lév. is a white rot fungus that is grown commercially for mushrooms in the northeast and north of Thailand. It has been reported that $L$. polychrous Lév. produced laccase as the main lignolytic enzyme involved in dye decolorisation (Budda et al., 2012; Khammuang and Sarnthima, 2007; Sarnthima et al., 2009). The cultivation of L. polychrous Lév. on solid substrates is a common practice and lignocellulosic agricultural waste is commonly used. In this work L. polychrous Lév. was cultivated on cassava rhizome and its capacity to decolorise aqueous solutions of dyes was studied. The effects of the initial moisture content of cassava rhizomes used for fungal cultivation, the temperature during decolorisation, and the $\mathrm{pH}$ of solutions of three dyes were investigated.

\section{MATERIAL AND METHODS}

\section{Materials}

Reactive blue 49, Acid blue 62, and Cibacron Navy blue WBT Crude (Navy blue) were supplied by Huntsman (Thailand), Dystar (Thailand), and Ciba Specialty Chemicals Industries, respectively. Cassava rhizomes were collected from Buriram Province, Thailand; they were sun-dried and chopped into small pieces of $0.85-1.4 \mathrm{~cm}$ in length. The chopped rhizomes were rinsed with tap water and oven dried at $105^{\circ} \mathrm{C}$ overnight before use. Lentinus polychrous Lév. was obtained from the Mushroom Collection Center, Clearing House Mechanism of the Department of Agriculture, Thailand. The fungus was maintained on Potato Dextrose Agar (PDA) at $30^{\circ} \mathrm{C}$ and transferred to Mushroom Complete Medium (MCM: 1 liter contained $20 \mathrm{~g}$ glucose, $2 \mathrm{~g}$ yeast extract, $0.5 \mathrm{~g} \mathrm{MgSO}_{4}, 1 \mathrm{~g} \mathrm{~K}_{2} \mathrm{HPO}_{4}$, $0.46 \mathrm{~g} \mathrm{KH}_{2} \mathrm{PO}_{4}$, and $15 \mathrm{~g}$ agar; its $\mathrm{pH}$ was 6.0 ) and incubation was for 5 days at $30^{\circ} \mathrm{C}$.

\section{Fungal cultivation}

The moisture content of the cassava rhizome was varied to investigate its effects on decolorisation. The moisture contents were adjusted by the addition of calculated quantities of distilled water and the mixtures were sterilised at $121^{\circ} \mathrm{C}$ for 30min. Single circular plugs $(1 \mathrm{~cm}$ diameter) excised from the inoculated and incubated MCM plates were added to $500 \mathrm{ml}$ Erlenmeyer flasks that contained $8 \mathrm{~g}$ dry weight of cassava rhizome. The moisture content of the cassava rhizome was varied to investigate its effect on decolorisation. When the other effects were studied, the moisture content of cassava rhizome was adjusted to $70 \%$. The cultures (in triplicate) were incubated at $37^{\circ} \mathrm{C}$ for 3 weeks. The evaporation of water during incubation was minimized by adding sterilized distilled water to replace the total weight loss of the cultures every second day. During the growth of fungi on solid substrates, loss of dry weight has been used as an index of the consumption of organic material in several earlier publications (Eichlerová et al., 2000; Nicolini et al., 1987; Zadrazil and Brunnert, 1980). The authors of these reports have shown that dry weight loss is positively correlated with the growth of fungi (Eichlerová et al., 2000; Nicolini et al., 1987). In this work, we have used dry weight loss as a rough measure of the extent of growth of L. polychrous. The dry weight loss of the culture was measured by oven drying at $105^{\circ} \mathrm{C}$ for $12 \mathrm{~h}$. 


\section{Determination of concentrations of synthetic dyes}

The concentrations of synthetic dyes in aqueous solutions were determined spectrophotometrically at the $\lambda_{\max }$ (visible) of the dyes using a Helios Gamma 9423 spectrophotometer (Thermospectronic, UK). The $\lambda_{\max }$ of Reactive blue 49, Acid blue 62, and Navy blue were 580, 640, and 600nm, respectively. Calibration employed solutions of the dyes in the concentration range $0-100 \mathrm{mg} / \mathrm{L}$ and plots of absorbance against concentration were linear.

\section{Decolorisation by L. polychrous Lév. cultivated on cassava rhizome}

To three week-old fungal cultures were added $250 \mathrm{ml}$ of the dye solutions $(50 \mathrm{mg}$ of dye/L in distilled water) which had been filter-sterilized $(0.45 \mu \mathrm{m}$ cellulose nitrate filter, Whatman). The mixtures were incubated at $37^{\circ} \mathrm{C}$ with agitation (rotary incubator, 200rpm). The concentrations of the dyes remaining in the liquid phases were determined at various times throughout the period of incubation. The oven dried $\left(105^{\circ} \mathrm{C}, 12 \mathrm{~h}\right)$ three-week old fungal cultures were used as the control. When the effects of temperature during decolorisation were studied, the mixtures were incubated at 30,37 and $45^{\circ} \mathrm{C}$. When the effects of $\mathrm{pH}$ on the extent of the decolorisation of the dyes were studied, the filter-sterilised dye solutions prepared in citrate-phosphate buffer $\left(0.1 \mathrm{M}\right.$ citric acid and $\left.0.2 \mathrm{M} \mathrm{Na}_{2} \mathrm{HPO}_{4}\right)$ adjusted to $\mathrm{pH}$ 3,5 , and 7 were used. In these experiments concerning the effects of temperature and $\mathrm{pH}$, the concentration of Navy blue in the solution used was $50 \mathrm{mg} / \mathrm{L}$ but those of Reactive blue 49 and Acid blue 62 were increased to $300 \mathrm{mg} / \mathrm{L}$.

\section{Determination of laccase activity at various pHs}

The extracts for the determination of activity were prepared by adding $250 \mathrm{ml}$ of distilled water to the cultures and agitating (200rpm) the mixtures for 1 hour at $30^{\circ} \mathrm{C}$. The liquid phases were separated by filtration (Whatman No. 4 paper). The activity of laccase in the liquid phases extracted from the 3 week-old cultures of L. polychrous Lév. after cultivation was measured by using the method of Johannes and Majcherczyk (2000). The reaction mixtures contained (final concentrations) $5 \mathrm{mM}$ ABTS [2,2'-azino-bis(3-ethylbenzothiazoline-6-sulphonic acid)], $0.1 \mathrm{M}$ citrate-phosphate buffer of various $\mathrm{pHs}$ in the range $3-7$, and $50 \mu 1$ of liquid phase. The concentration of oxidized ABTS produced after $5 \mathrm{~min}$ was determined from the increase in absorbance at $420 \mathrm{~nm} .\left(\varepsilon=36,000 \mathrm{M}^{-1} \mathrm{~cm}^{-1}\right)$.

\section{Determination of the stability of laccase activity at various pHs}

The extracts of the enzyme were prepared by adding $100 \mathrm{ml}$ of water to the cultures. After agitation and filtration as described above, $10 \mathrm{ml}$ of liquid phase were added to $15 \mathrm{ml}$ of $0.167 \mathrm{M}$ citrate-phosphate buffer of a $\mathrm{pH}$ within the range of 3-7. The mixtures were incubated at $37^{\circ} \mathrm{C}$ for various times. At these times, laccase activity at $\mathrm{pH} 3$ was determined with $50 \mu 1$ portions of the diluted liquid phases as described above.

\section{RESULTS AND DISCUSSION}

The effects on decolorisation of the initial moisture content of cassava rhizome used for fungal cultivation

The greatest extent of decolorisation was observed when L. polychrous Lév. was cultivated on cassava rhizome with $70 \%$ initial moisture content (figure 1). Moisture content is the main characteristic of solid substrate cultivation processes that controls growth and the metabolic systems of microorganisms (PérezGuerra et al., 2003). Reactive Blue 49 was extensively decolorised by cultures cultivated at $50 \%$ moisture content and only a slight increase in the extent of decolorisation was observed when the moisture content of the substrate was $70 \%$ (figure 1A). These results are correlated with the dry weight loss of the substrate at 70 and $50 \%$ moisture content (figure 2). On the other hand, very different extents of decolorisation of solutions of Navy Blue were observed when cassava rhizome with $70 \%$ and $50 \%$ moisture contents were used (figure 1C). However, the results of figure 2 merely indicate the extent of consumption of organic material by the growth of the fungus. During solid state cultivation, microorganisms usually require more water to produce metabolites and enzymes than to promote growth (Pérez-Guerra et al., 2003). The results of figures 1A-D show clearly that the two dyestuffs which were decolorised mainly by enzymic degredation were decolorised more extensively when the moisture content of the cassava rhizomes used for fungal cultivation was increased. This phenomenon is due perhaps to the larger amounts of fungal degradative enzymes that are produced at less restricting moisture contents. Decolorisation by L. polychrous Lév. grown on cassava rhizome occurred via two mechanisms: enzymic degradation and adsorption onto both the cassava rhizome and the fungal mycelium. In this study, inactivated cultures were used to estimate the extent of adsorption of dyestuffs onto cassava rhizomes and the fungal mycelium (figure 1B, 1D, and 1F). Acid blue 62 was adsorbed most extensively onto cassava rhizome and fungal mycelium (figure 1F). Approximately $80 \%$ of Acid blue 62 was removed from the liquid phase while only $40-50 \%$ and $15 \%$ of Reactive blue 49 and Navy blue, respectively, were adsorbed. Acid blue 62 is an acidic sulphonated dye of relatively low molecular weight while Reactive blue 49 and Navy blue are reactive dyes (Zollinger, 2013). Several factors, e.g. chemical structure, substrate affinity, $\mathrm{pH}$, temperature, ions present in solution, affect adsorption and the mechanisms of adsorption of these dyestuffs onto the mixture of cassava rhizome and the fungal mycelium require further investigation.

\section{The effects of temperature on decolorisation}

Because Reactive blue 49 and Acid blue 62 were very extentsively decolorised when the concentration of the dyes used was $50 \mathrm{mg} / \mathrm{L}$, it was decided to increase the concentration of these dyes to $300 \mathrm{mg} / \mathrm{L}$ in order to ensure that there was sufficient dye to act as substrate for ligninolytic enzymes to reveal clearly if there were any effects caused by variation of temperature and $\mathrm{pH}$.

The temperature at which the solutions of dyes were treated might affect adsorption capacity and the amounts and activities of the enzymes produced. The optimum temperature of crude laccase, the predominant enzyme produced by $L$. polychrous, is $55^{\circ} \mathrm{C}$ and its activity at $30^{\circ} \mathrm{C}$ is approximately $45 \%$ of that at the optimum temperature (Budda et al., 2012). The results shown in figure 3 demonstrate clearly that temperatures between $30-45^{\circ} \mathrm{C}$ had no significant effect on the extent of decolorisation of the dyestuffs examined. Even when the concentrations of Reactive blue 49 and Acid blue 62 were increased from 50 to $300 \mathrm{mg} / \mathrm{L}$, more than $93 \%$ decolorisation of all of the dyes was achieved Presumably, during cultivation of L. polychrous Lév. on cassava rhizome with $70 \%$ initial moisture content there was sufficient water not to restrict the production of the degradative enzymes involved in the decolorisation of the dyestuffs.

\section{The effects of $\mathrm{pH}$ of the solutions of dyes on decolorisation}

Enzyme activity varies with $\mathrm{pH}$ and citrate-phosphate buffer was selected to control the $\mathrm{pH}$ of dye solutions during decolorisation because it provides buffering capacity over a wide range. It was suspected that the activity of fungal laccase was inhibited by this buffer in the $\mathrm{pH}$ range of 3-7 because of the delay of the onset of decolorisation of the dyes ( $\mathrm{cf}$ the results in figures 3 and 4). Moreover, laccase activities of extracts prepared with water were always higher than those of extracts prepared with citrate-phosphate buffer of any $\mathrm{pH}$. $\mathrm{pH} 3$ was the optimum $\mathrm{pH}$ for the decolorisation of Reactive 49 and Acid blue 62 (figure 4A and $4 \mathrm{E}$ ) and it is interesting to note that the optimum $\mathrm{pH}$ of laccase produced by L. polychrous is 3.0 (Budda et al. 2012). The results of figure 5A show that maximum laccase activity also was observed at this $\mathrm{pH}$ under these experimental conditions.

The suspected inhibition of the ligninolytic enzyme by the components of citratephosphate buffer might have had a significant effect on the degradation of the recalcitrant dyestuff; Navy blue did not undergo degradation (Figure 4C). Even although the laccase produced by L. polychrous Lév. in this study had its maximum activity at $\mathrm{pH} 3$ (figure $5 \mathrm{~A}$ ), it was unstable on storage at $37^{\circ} \mathrm{C}$ in citrate-phosphate buffer of $\mathrm{pH} 3$ (figure 5B). This observation might explain why decolorisation of Reactive blue 49 was delayed during the first 12 hours of incubation at $\mathrm{pH} 3$ (see figures $4 \mathrm{~A}$ and $3 \mathrm{~A}$ ).

The effects of $\mathrm{pH}$ on adsorption of dyestuffs onto the mixture of cassava rhizome and fungal mycelium are illustrated in figures $4 \mathrm{~B}, 4 \mathrm{D}$, and $4 \mathrm{~F}$. Various effects were observed, presumably caused by the different chemical structures and affinities of the dyes for the solid substrate. Generally, the most effective dyeing conditions for acid dyes are at acidic $\mathrm{pH}$ (Zollinger, 2003). Acid blue 62, an acid dye, was adsorbed most extensively at $\mathrm{pH} 3$. However, it was adsorbed almost as extensively at $\mathrm{pH} 5$ and 7 (figure 4F). Dyeing cellulose fiber with reactive dyes demands alkaline conditions in order to promote covalent bonding (Zollinger, 2003). Although Reactive blue 49 is a reactive dye, it also is a sulphonated anionic species. Therefore, it might be expected to be adsorbed most extensively at $\mathrm{pH} 3$, as was Acid blue 62. Moreover, citrate and phosphate in the buffer might also affect the extent of adsorption.

Acid blue 62 was decolorised most effectively, followed by Reactive blue 49 and then Navy blue (figure 4). The chemical structure of the dye also profoundly influences the degradative capability of white rot fungi. Jarosz-Wilkolazka et al. (2002) found that the azo dye, Acid Red 183, was more resistant to degradation by some white rot fungal strains than the anthraquinone Basis blue 22. In addition, Eichlerová et al. (2006) showed that anthraquinones were biodegraded by Dichomitus squalens much more rapidly than azo dyes. Eichlerová et al. (2006) also suggested that azo dyes were more recalcitrant because azo compounds are rarely encountered in nature. 
A

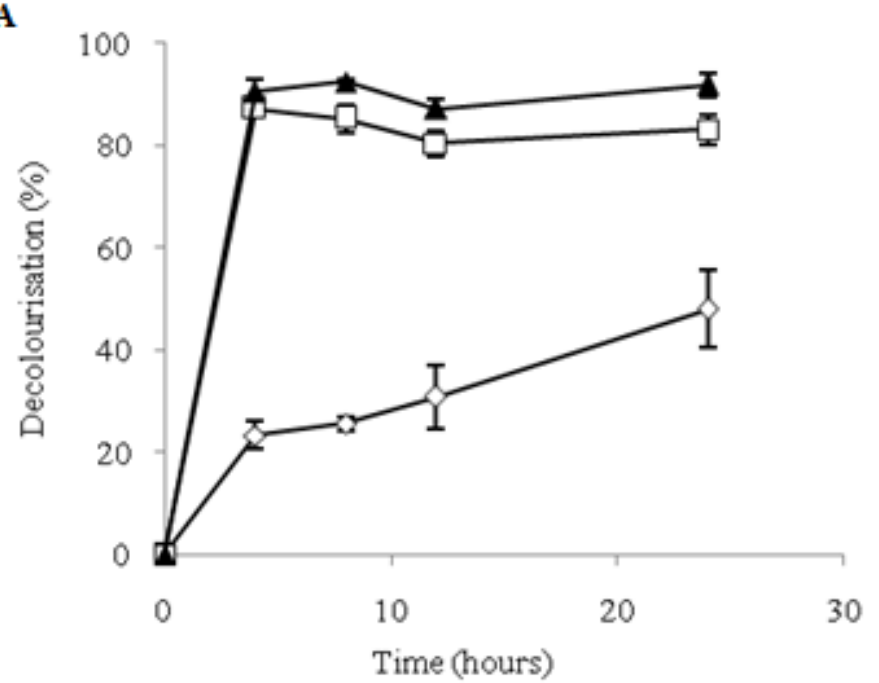

C

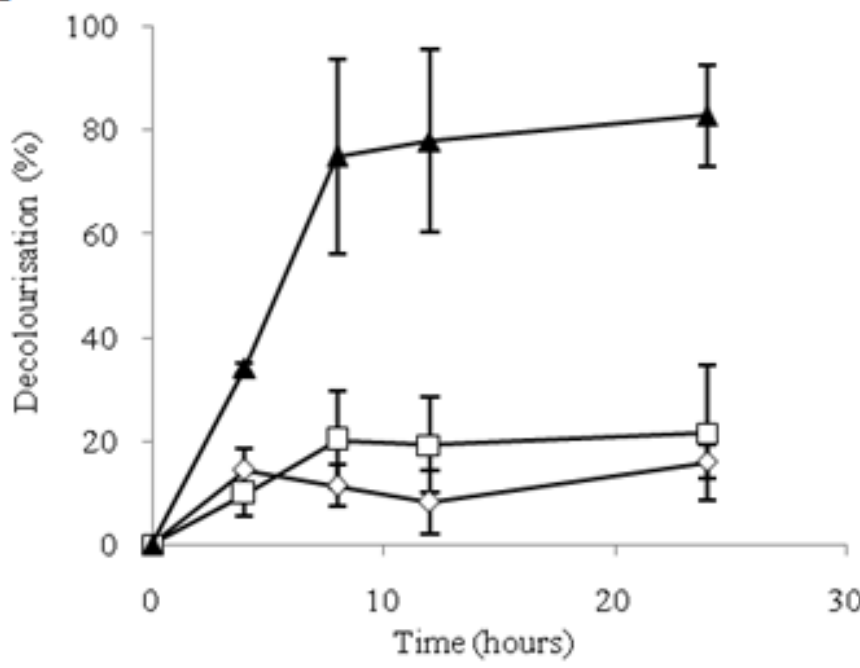

E

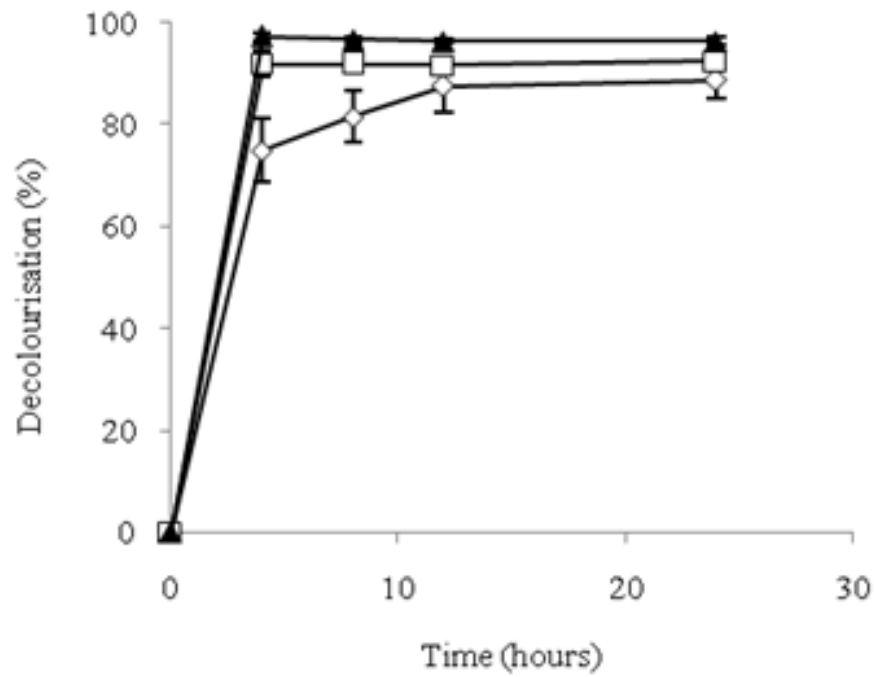

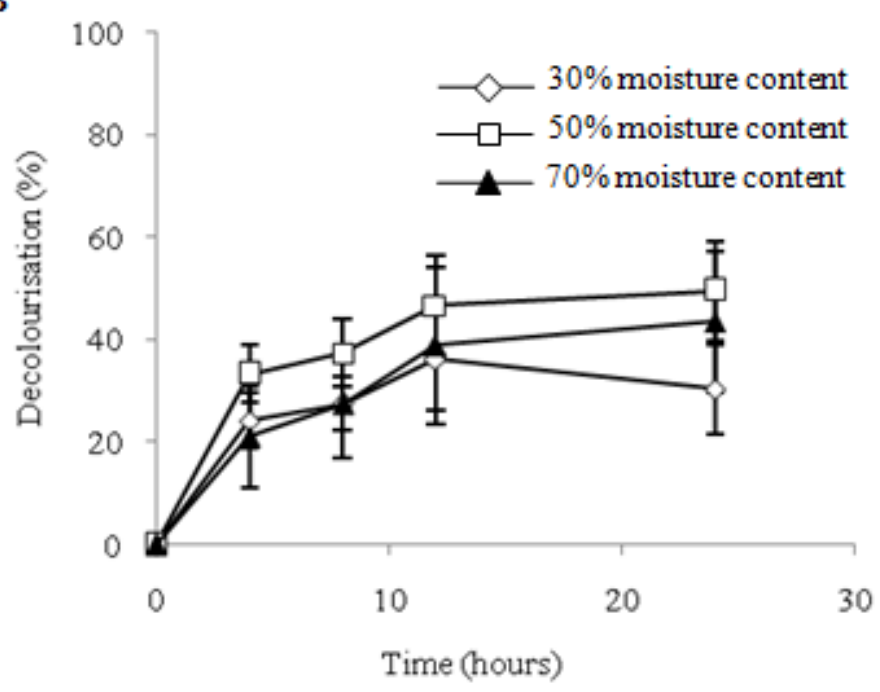

D

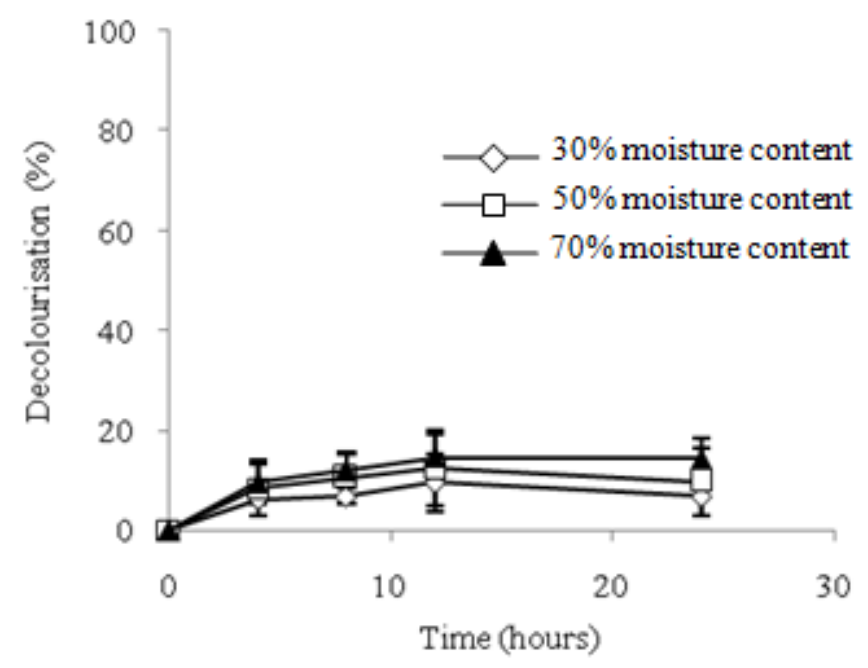

$\mathbf{F}$

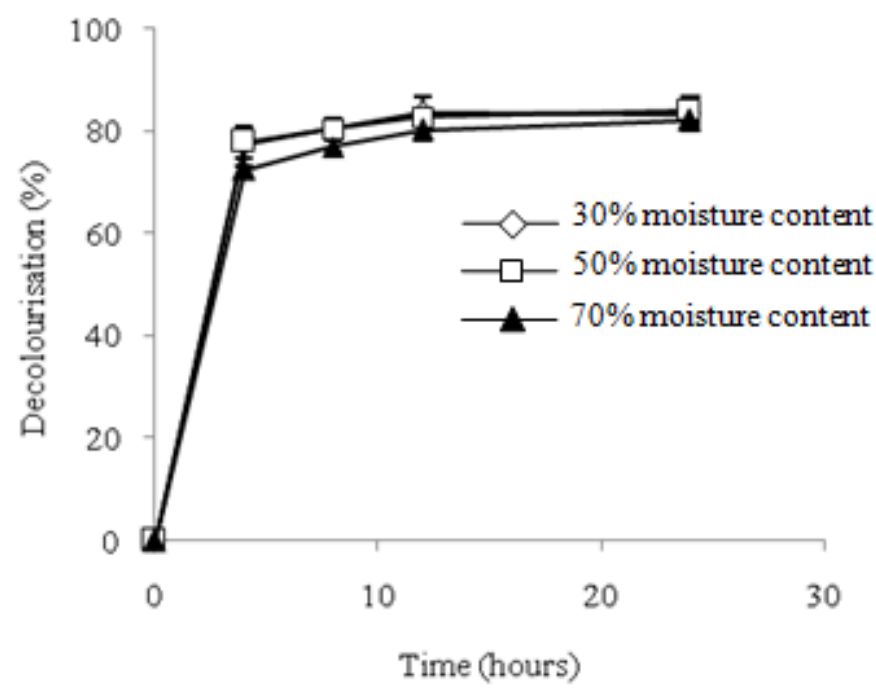

Figure 1 Decolorisation by L. polychrous Lév. cultivated on cassava rhizome at different initial moisture contents. (A) active culture, Reactive blue 49, (B) inactivated culture, Reactive blue 49, (C) active culture, Navy blue, (D) inactivated culture, Navy blue, (E) active culture, Acid blue 62, and (F) inactivated culture, Acid blue 62 


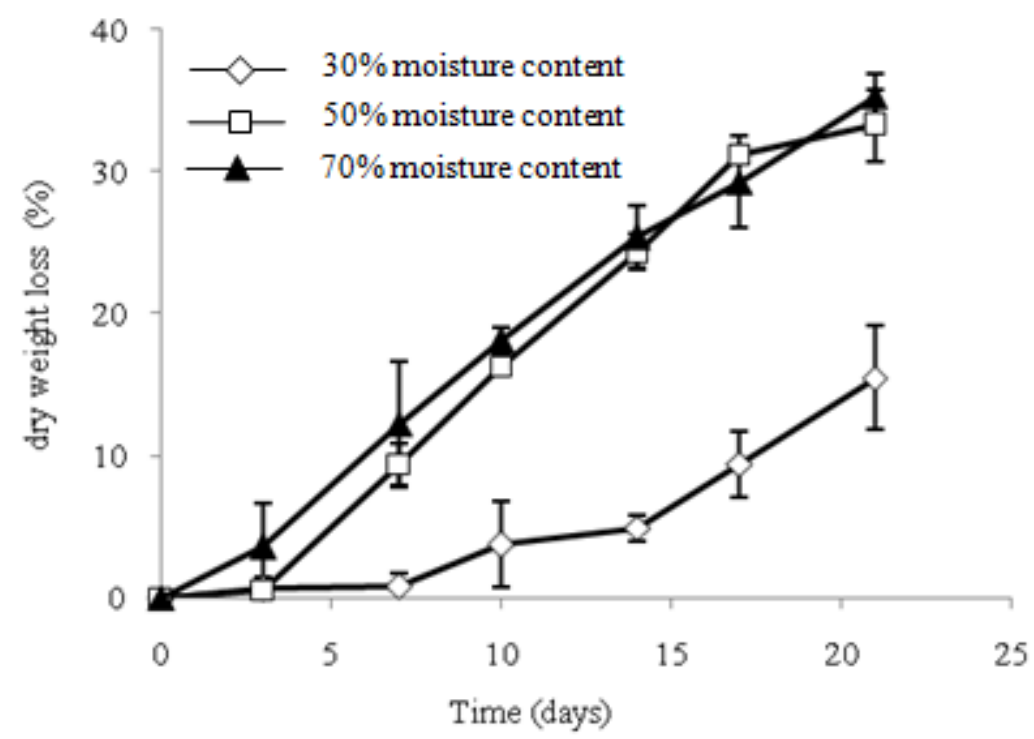

Figure 2 Dry weight loss of cultures of L. polychrous Lév. grown on cassava rhizome at different initial moisture contents

A

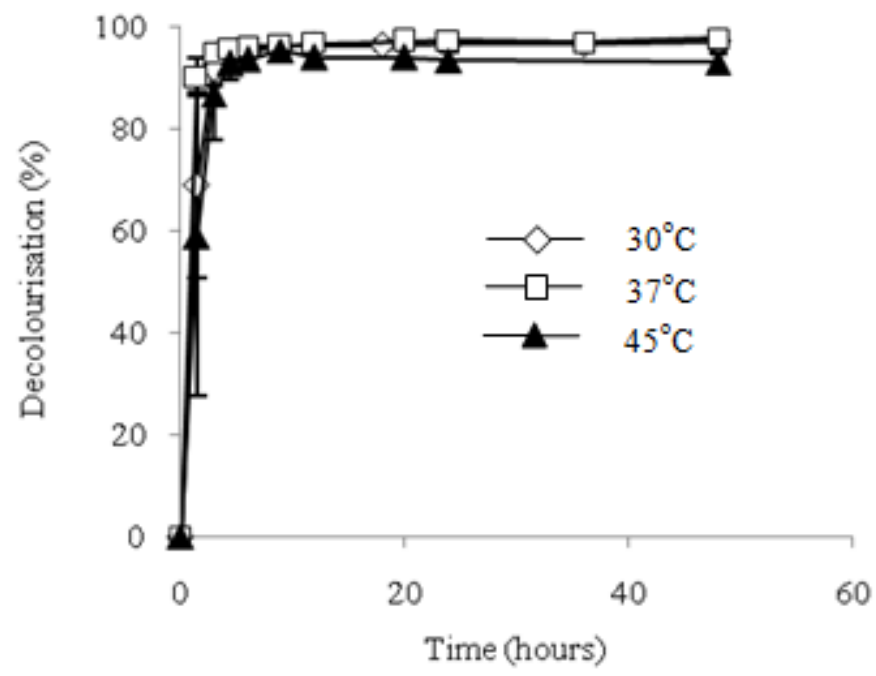

B

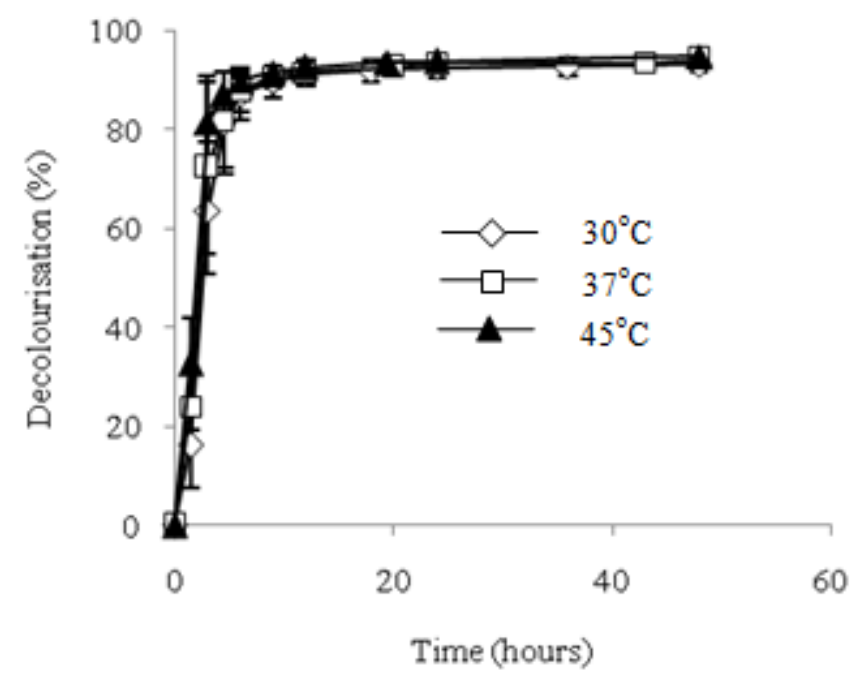

C

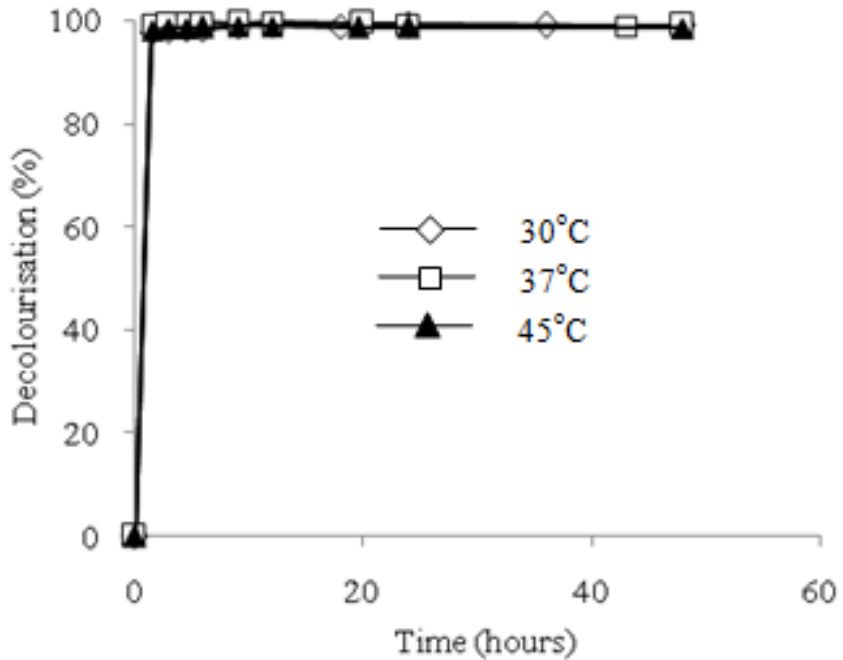

Figure 3 Extents of decolorisation at different temperatures by L. polychrous Lév. grown on cassava rhizome. (A) Reactive blue 49, (B) Navy blue and (C) Acid blue 62

The solutions of dyes were prepared with distilled water (see the Materials and Methods). 

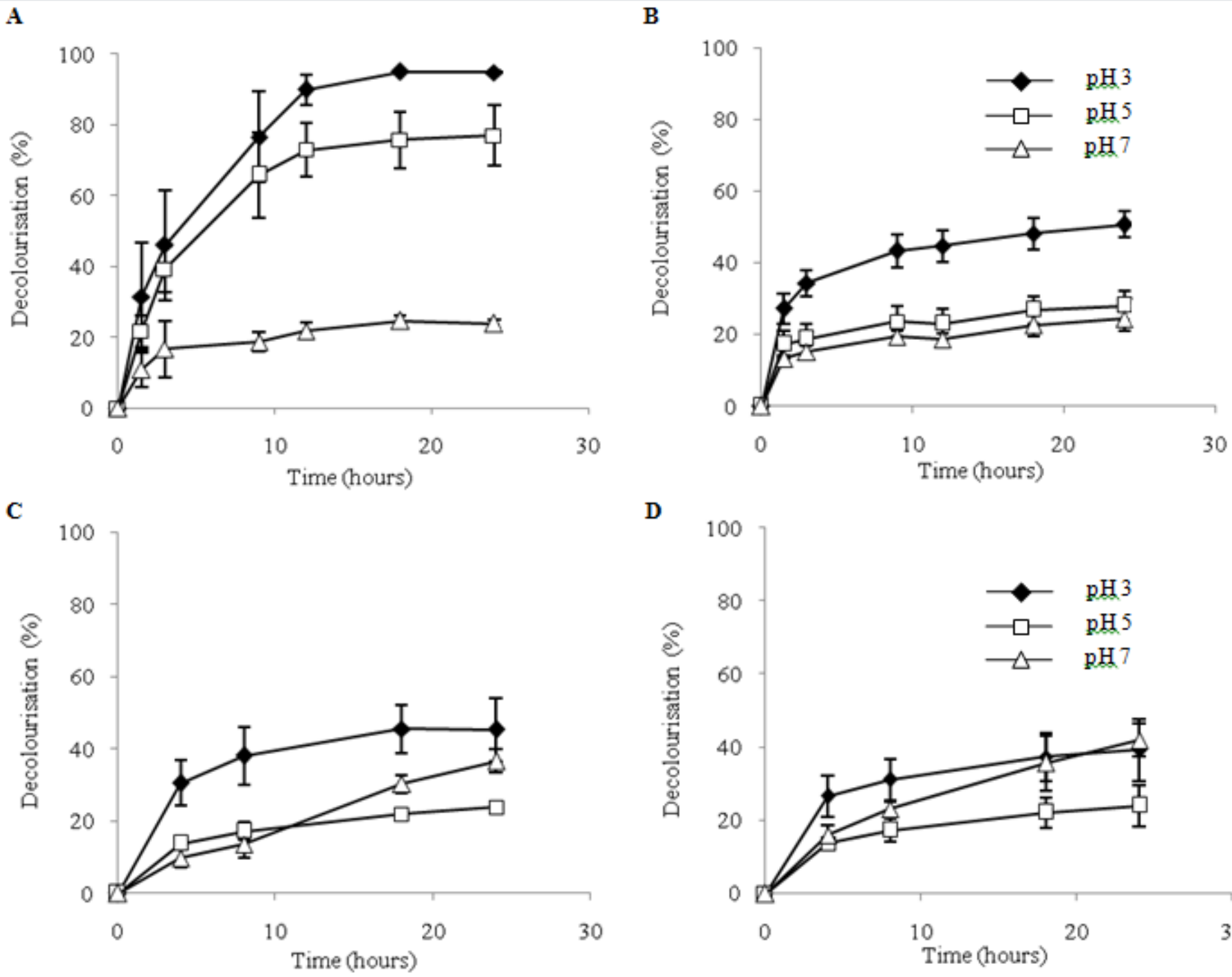

D

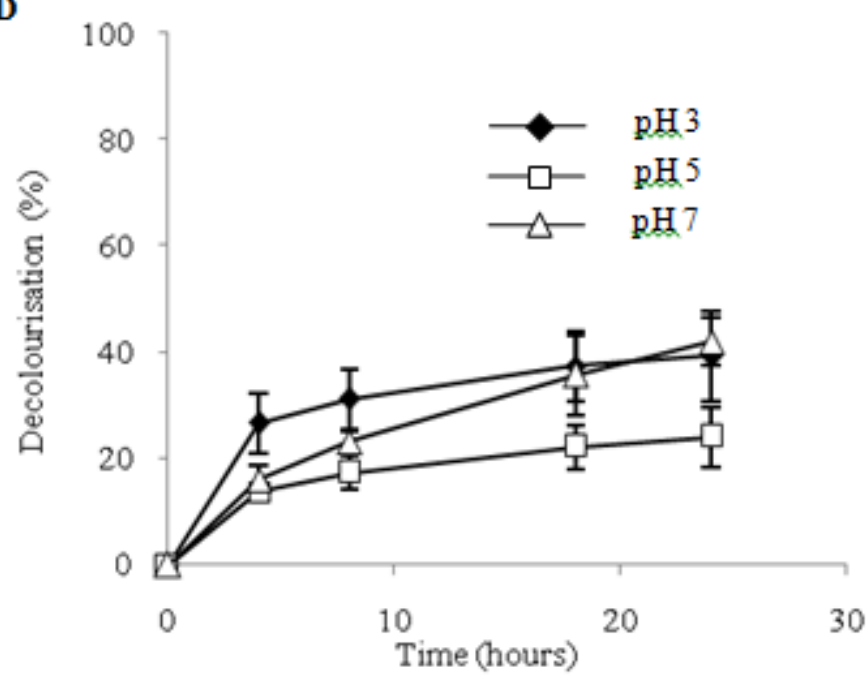

E

F
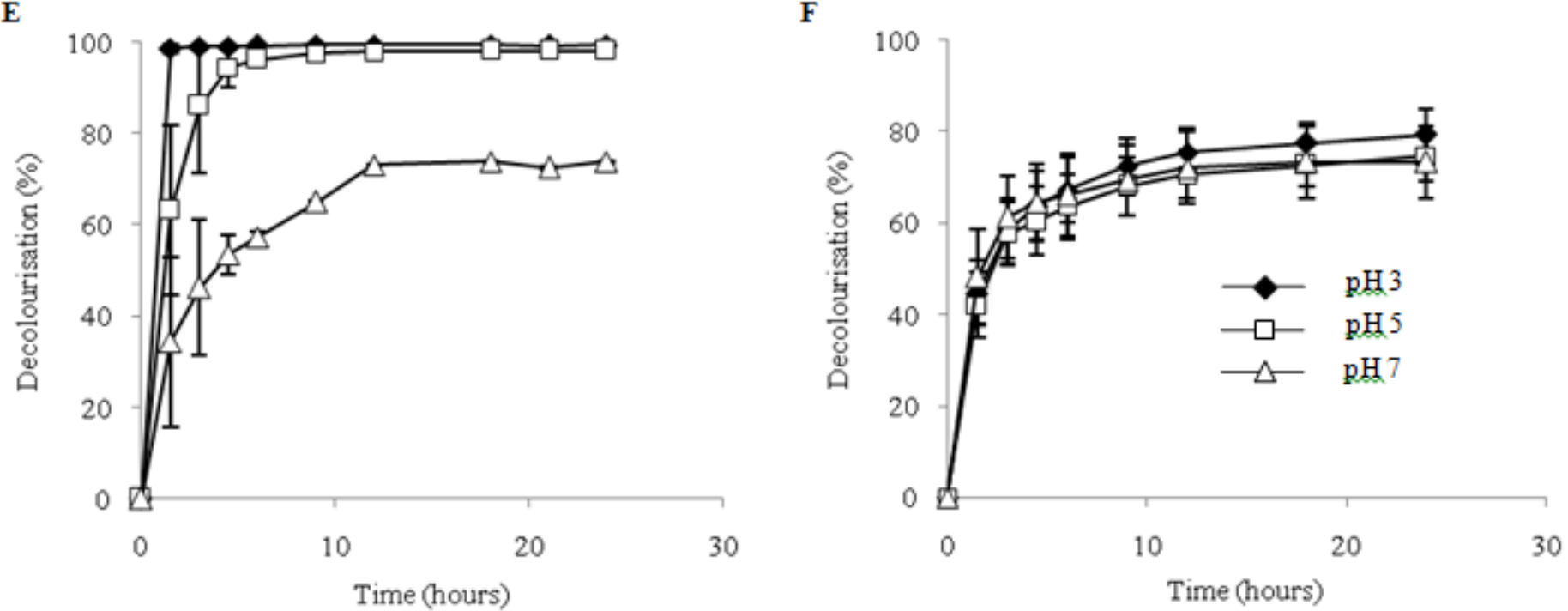

Figure 4 Decolorisation of solutions of dyes at various $\mathrm{pHs}$ by L. polychrous Lév. cultivated on cassava rhizome. (A) active culture, Reactive blue 49, (B) inactivated culture, Reactive blue 49, (C) active culture, Navy blue, (D) inactivated culture, Navy blue, (E) active culture, Acid blue 62, (F) inactivated culture, Acid blue 62 The solutions of dyes were prepared with citrate-phosphate buffers (see the Materials and Methods)

The effects of $\mathrm{pH}$ on adsorption of dyestuffs onto the mixture of cassava rhizome and fungal mycelium are illustrated in figures $4 \mathrm{~B}, 4 \mathrm{D}$, and $4 \mathrm{~F}$. Various effects were observed, presumably caused by the different chemical structures and affinities of the dyes for the solid substrate. Generally, the most effective dyeing conditions for acid dyes are at acidic $\mathrm{pH}$ (Zollinger, 2003). Acid blue 62, an acid dye, was adsorbed most extensively at $\mathrm{pH}$ 3. However, it was adsorbed almost as extensively at $\mathrm{pH} 5$ and 7 (figure 4F). Dyeing cellulose fiber with reactive dyes demands alkaline conditions in order to promote covalent bonding (Zollinger, 2003). Although Reactive blue 49 is a reactive dye, it also is a sulphonated anionic species. Therefore, it might be expected to be adsorbed most extensively at $\mathrm{pH} 3$, as was Acid blue 62. Moreover, citrate and phosphate in the buffer might also affect the extent of adsorption. 
A

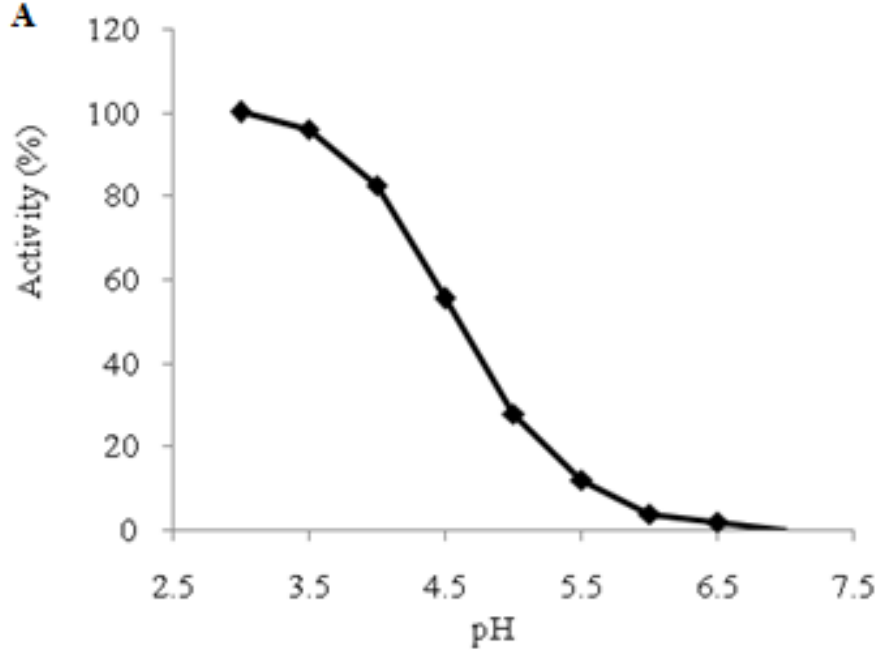

B

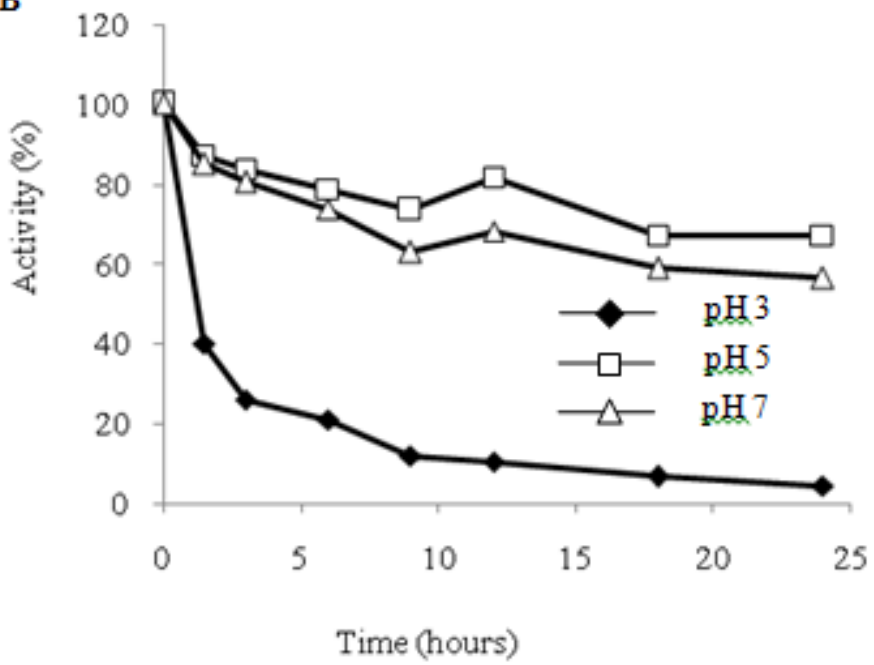

Figure 5 Activities (A) and stability at $37^{\circ} \mathrm{C}(\mathrm{B})$ at various pHs of laccase produced by L. polychrous Lév. grown on cassava rhizome. (A) Activity (Y-axis) is the percentage of the activity observed at $\mathrm{pH} 3$ (B) Activity (Y-axis) is the percentage of the activity observed at zero hours of storage at $37^{\circ} \mathrm{C}$. See the Materials and Methods.

Acid blue 62 was decolorised most effectively, followed by Reactive blue 49 and then Navy blue (figure 4). The chemical structure of the dye also profoundly influences the degradative capability of white rot fungi. Jarosz-Wilkolazka et al. (2002) found that the azo dye, Acid Red 183, was more resistant to degradation by some white rot fungal strains than the anthraquinone Basis blue 22. In addition, Eichlerová et al. (2006) showed that anthraquinones were biodegraded by Dichomitus squalens much more rapidly than azo dyes. Eichlerová et al. (2006) also suggested that azo dyes were more recalcitrant because azo compounds are rarely encountered in nature.

\section{CONCLUSION}

The moisture content of cassava rhizome used for fungal cultivation had a significant impact on the extent of decolorisation of aqueous solutions of synthetic dyes when enzymic degradation was the main mechanism of decolorisation. The highest extent of decolorisation was observed when the moisture content of the cassava rhizome used for fungal cultivation was $70 \%$. Temperatures between $30^{\circ} \mathrm{C}-45^{\circ} \mathrm{C}$ did not affect the extent of decolorisation. The optimum $\mathrm{pH}$ for enzymic degradation by laccase was 3.0. The effect of $\mathrm{pH}$ on the adsorption of dyestuffs onto the mixture of cassava rhizome and fungal mycelium depended on the molecular structure of the dyestuff. The anthraquinone reactive dye (Reactive blue 49) was adsorbed most at $\mathrm{pH} 3$, while $\mathrm{pHs}$ from $3.0-7.0$ did not influence the adsorption of the acidic anthraquinone (Acid blue 62). The reactive azo dye Navy blue was adsorbed extensively at $\mathrm{pH} 3.0$ and 7.0. It was suspected that the components of the buffer used to control $\mathrm{pH}$ (citrate-phosphate) inhibited the degradative enzymes produced by L. polychrous Lév.

Acknowledgments: We are indebted to the Kasetsart University Research and Development Institute (KURDI), Thailand for financial support.

\section{REFERENCES}

BUDDA, W., SARNTHIMA, R., KHAMMUANG, S., MILINTAWISAMAI, N., NAKNIL, S. 2012. Ligninolytic enzymes of Lentinus polychrous grown on solid substrates and its application in black liquor treatment. Journal of Biological Science, 12(1), 25-33. http://dx.doi.org/10.3923/jbs.2012.25.33

EICHLEROVÁ, I., HOMOLKA, L., NERUD, F. 2006. Synthetic dyes decolorization capacity of white rot fungus Dichomitus squalens. Bioresource Technology, 97, 2153-2159. http://dx.doi.org/10.1016/j.biortech.2005.09.14 EICHLEROVÁ, I., HOMOLKA, L., NERUD, F., ZADRAZIL, F., BALDRIAN, P., GABRIEL, J. 2000. Screening of Pluerotus ostreatus isolates for their ligninolytic properties during cultivation on natural substrates. Biodegradation, 11, 279-287.

FAO. 2014. Food and agriculture organization of the United Nations statistics division. [Online]. Available at: http://faostat3.fao.org/download/Q/QC/E [Accessed: 2014, October 18].

HOMCHAT, K., SUCHARITAKUL, T., KHANTIKOMOL, P. 2012. The experimental study on pyrolysis of the cassava rhizome in the large scale metal kiln using flue gas. Energy Procedia, 14, 1684-1688 http://dx.doi.org/10.1016/j.egypro.2011.12.1152
JAROSZ-WILKOLAZKA, A., KOCHMAŃSKA-RDEST, J., MALARCZY, E., WARDAS, W., LEONOWICZ, A. 2002. Fungi and their ability to decolourize azo and anthraquinonic dyes. Enzyme Microbiology Technology, 30, 566-572.

JOHANNES, C., MAJCHERCZYK, A. 2000. Laccase activity tests and laccase inhibitors. Journal of Biotechnology, 78, 193-199.

KHAMMUANG, S., SARNTHIMA, R. 2007. Laccase from spent mushroom compost of Lentinus polychrous Lév. and its potential for Remazol Brilliant Blue $\mathrm{R}$ decolorisation. Biotechnology, 6, 408-413. http://dx.doi.org/10.3923/biotech.2007.408.413

NICOLINI, L., VON HUNOLSTEIN, C., CARILlI, A. 1987. Solid state fermentation of orange peel and grape stalks by Pleurotus ostreatus, Agrocybe aegerita, and Armillariella mellea. Applied Micriobiolgy and Biotechnology, 26, 95-98.

PATTIYA, A., TITILOYE, J.O., BRIGEWATER, A.V. 2010. Evaluation of catalytic pyrolysis of cassava rhizome by principal component analysis. Fuel, 89 , 244-253. http://dx.doi.org/10.1016/j.fuel.2009.07.003

PÉREZ-GUERRA, N., TORRADO-AGRASAR, A., LÓPEZ-MACIAS, C. PASTRANA, L. 2003. Main characteristics and applications of solid substrate fermentation. Electronic Journal of Environmental Agricultural and Food Chemistry, 2, 343-350.

SARNTHIMA, R., KHAMMUANG, S., SVASTI, J. 2009. Extracellular ligninolytic enzymes by Lentinus polychrous Lév. under solid-state fermentation of potential agro-industrial wastes and their effectiveness in decolorisation of synthetic dyes. Biotechnology Bioprocess Engineering, 14, 513-522. http://dx.doi.org/10.1007/s12257-008-0262-6

SIRIJANUSORN, S., SRIPRATEEP, K., PATTIYA, A. 2013. Pyrolysis of cassava rhizome in a counter-rotating twin screw reactor unit. Bioresource Technology, 139, 343-348. http://dx.doi.org/10.1016/j.biortech.2013.04.024

SORNKADE, P., ATONG, D., SRICHAROENCHAIKUL, V. 2013 Enhancement of cassava rhizome gasification using mono - metallic cobal $\begin{array}{llll}\text { catalysts. } & \text { Energy } & \text { Procedia, } & \text { 273-281. }\end{array}$ http://dx.doi.org/10.1016/j.egypro.2013.06.755

SORNKADE, P., ATONG, D., SRICHAROENCHAIKUL, V. 2014. Conversion of cassava rhizome using an in-situ catalytic drop tube reactor for fuel gas generation. Renewable Engergy. http://dx.doi.org/10.1016/j.renene.2014.07.043 SUKUMAR, M., SIVASAME, A., SWAMINATHAN, G. 2007. Decolorization of textile dye effluent by genetically improved bacterial strains. Applied Biochemistry and Biotechnology, 136(1), 53-62.

SUTTIBAK, S., SRIPRATEEP, K., PATTIYA, A. 2012. Production of bio-oil via fast pyrolysis of cassava rhizome in a fluidised-bed reactor. Enery Procedia, 14, 668-673. http://dx.doi.org/10.1016/j.egypro.2011.12.993

WESENBERG, D., KYRIAKIDES, I., AGATHOS, S.N. 2003. White-rot fungi and their enzymes for the treatment of industrial dye effluents. Biotechnology Advance, 22, 161-187. http://dx.doi.org/10.1016/j.biotechadv.2003.08.011

ZADRAZIL, F., BRUNNERT, H. 1980. The influence of ammonium nitrate supplementation on degradation and in vitro digestibility of straw colonized by higher fungi. European Journal of Applied Microbiology and Biotechnology, 9 , 37-44.

ZOLLINGER, H. 2003. Color Chemistry: Syntheses, Properties, and Applications of Organic Dyes and Pigments. Zurich: Wiley-VCH, 637p. ISBN 3-906390-23-3. 